Pereira, D.; Niklasson, L. \& Flores, M. A. (2017) Students' perceptions of assessment: a comparative analysis between Portugal and Sweden, Higher Education, 73(1), pp. 153-173

\title{
Introduction
}

Understanding the assessment process, including the concepts and methods used, is essential to educational practice. In recent years new trends on assessment have emerged from an integrated perspective of the teaching, learning and assessment process (Rust 2007). In contrast to summative assessment, which can be perceived as mainly using assessment to certify student achievement (Boud and Falchikov 2006; Hernández 2012), formative assessment supports and monitors the students' learning, providing continuous feedback during the process (Yorke 2003; Weurlander et al. 2012), and informing them about their performance (Boud 1990; Brown and Knight 1994; Brew et al. 2009). These trends have introduced new methods of assessment (Brew et al. 2009) and more participatory practices, such as self, peer, and coassessment (Dochy, Segers and Sluijsmans 1999).

A review of research in higher education after the introduction of the Bologna process (Bologna Declaration 1999) showed that there is increased interest in learner-oriented assessment (Pereira, Flores and Niklasson 2015). One aspect of this orientation can be seen in students' perceptions about learning and assessment. Students' perceptions of the learning environment (Entwistle 1991; Lizzio and Wilson 2013) and assessment methods influence the ways in which students learn (Entwistle and Entwistle 1991; Ramsden 1992; Lizzio and Wilson 2013) and their approaches to learning (Marton and Säljö 1997).

Although assessment has been the focus of several studies, there is still a lack of research about the use of assessment practices across different institutions and countries in a comparative perspective (Gilles et al. 2011; Fletcher et al. 2012). One reason for lack of studies can be related to the challenges, such as difficulties in reaching consensus in a research team (Teichler 2014). Despite the challenges, in response to this apparent lack of research about methods of assessment, the aim of this study is to carry 
out a comparative analysis between Portugal and Sweden concerning student perceptions and experiences of assessment. The following questions are addressed:

1) What issues emerge concerning assessment in the Portuguese and Swedish educational systems?

2) Which main differences can be traced while comparing students in the Portuguese and Swedish educational systems?

3) What implications of the results are there for assessment in higher education?

\section{Earlier Studies on Assessment}

Existing literature reveals that assessment has an important impact on student learning (Scouller 1998; Biggs 2003), as assessment and learning are interconnected (Scouller 1998; Light and Cox 2003). Gibbs and Simpson (2004) found that assessment, not teaching, is what influences students most in the entire learning process, and contrary to what might be expected, assessment takes up the majority of teaching time.

Earlier studies found that how students perceive the nature of the assessment tasks used influences the assessment process and their own learning (Sambell and McDowell 1998), sometimes experiencing negative feelings towards assessment such as stress and anxiety that reduces their academic performance (Craddock and Mathias 2009). Further, assessment can lead to different reactions and feelings. When Race (1995) asked a group of students about their perceptions about one-time examination versus continuous assessment the results showed a mixture of emotions and feelings, either negative or positive, concerning these assessment methods. The positive aspects relating to the examination reveal issues associated with a feeling of accomplishment such as relief, triumph, and getting it over with quickly. However, the negative aspects of fear, panic, stress and nervousness are related to feelings of insecurity, indecision, and fear of failure.

The positive aspects related to continuous assessment show more emotions related to learning, such as relationship with the task and learning material, and best opportunity to search for information/research. The negative aspects highlighted in the continuous assessment are more related to time management and inconvenience, since continuous 
assessment is a longer, more arduous assessment process. Boud (1995) also found that a majority of students have experienced negative situations and feelings with regard to assessment, multiple times and at different levels of education. Student perceptions and feelings about assessment, whether positive or negative, can be related to different assessment methods. Perceptions of the fairness and effectiveness of assessment are also important issues (Sambell et al. 1997). Gilles et al. (2011) state that students expect that the assessment tasks used by teachers will be fair.

The assessment methods used by teachers in higher education are important pedagogical tools, since the chosen method influences student learning to a large extent. Several authors (Struyven et al. 2005; Birenbaum and Feldman 1998; Sambell et al. 1997) argue that the use of different assessment methods leads to and determines different approaches to learning. Other studies are focused on student preferences for different assessment methods (Birenbaum and Feldman 1998; Sambell et al. 1997; Sambell and McDowell 1998; Weurlander et al. 2012); the same assessment method has different meanings for each student (Sambell and McDowell 1998), and students' motivation can be affected by several methods of assessment designed by different teachers (Weurlander et al. 2012). Empirical studies show that students with high academic confidence and good skills prefer essays. On the contrary, students with low academic confidence and poor skills prefer multiple choice tests (Birenbaum and Feldman 1998). Incidentally, essays lead to a deep approach to learning and multiple choice tests lead to a surface approach to learning (Entwistle and Entwistle 1991). On the one hand, students perceive traditional assessment (such as written tests) as negative to the learning process, since for example when a student takes an exam at a specific time there are different factors that determine the performance of the student, such as stress, anxiety or even feeling sick that day. On the other hand, students perceive new methods of assessment such as projects, portfolios, simulations, among others (Flores et al. 2015) as positive because they are consistent and based on effort (Sambell et al. 1997). Furthermore, these methods develop critical thinking and deep approaches to learning (Segers and Dochy 2001).

The emergence of non-traditional methods of assessment in higher education has produced several conceptions of assessment, such as "Learner-Centred Assessment." In this conception, the focus is on the student and the scope is to create learning 
environments that enable students to construct their own knowledge, in contrast to a more traditional design that focuses on transferring knowledge (Webber 2012). LearnerCentred Assessment is also considered by Webber (2012) an appropriate approach that increases value to higher education pedagogy, contrary to traditional assessment. Accordingly, earlier literature shows that a learner-centred assessment is perceived by students as fairer and more effective (Flores et al. 2015), promoting real-world experiences (Duncan and Buskirk-Cohen 2011), problem solving (Goubeaud and Yan 2004), deep approaches to learning (Brew, Riley, and Walta 2009) and involving students on the learning process promoting feedback (Huba and Freed 2000). However, these innovative and non-traditional assessment methods should be aligned with innovative teaching methods (Nieweg 2004).

Self and peer assessment are important in a feedback process in order to regulate the learning process. Self-assessment is responsible for developing good skills of autonomy and responsibility in students (Lew et al. 2009), producing feedback that allows students to understand the development of their learning (Mok et al. 2006; Lew et al. 2009:136) and preparing them for their professional life (Taras 2010). Self-assessment also encourages students to be active and to engage in their own performance process, allowing reflection and evaluation of their own work (Paris and Paris 2001). Peer assessment allows student engagement and produces formative and timely feedback (Vickerman 2009). Furthermore, peer assessment encourages collaborative work, deep thinking, reflection (Segers and Dochy 2001), and the development of transferrable skills (McGarr and Clifford 2013). The quality of learning is improved using methods such as peer assessment in higher education (McDowell and Mowl 1996). To sum up, self and peer assessment are to be preferred in higher education, since these methods enhance learning and develop student assessment skills (Norrie 2003). These methods can also develop evaluative "expertise" (Carless 2015), promote "assessment literacy" (Price et al. 2012) for students, and enhance learning.

The studies described above highlight some of the ongoing issues concerning assessment. In summary, assessment is not a new idea, especially not in education. On the other hand, the context is constantly changing and from using assessment for sorting and controlling, assessment now is more often used in both a formative and summative way. Differences are also found in who is carrying out the assessment, such as the 
teacher, peers, or students themselves. Apart from the distinction between formative and summative assessment, there are different methods of assessment. Traditional methods like tests and non-traditional methods like portfolios are both used. In addition to the use of assessment and its methods, a research area is students' feelings towards different kinds of assessment as they affect both assessment in itself and the learning situation. The assessment methods used and student perception are also influenced and framed by national education systems. In the next section the context for higher education in Portugal and Sweden is briefly presented.

\section{Portuguese and Swedish Higher Education System}

At the higher education level both Portugal and Sweden have adopted the Bologna Process (Bologna Declaration 1999). In these countries higher education is organised as a structure of three cycles: bachelor, master's, and doctorate. The first corresponds to undergraduate education and the second and third cycle to postgraduate education in the majority of the programmes. Higher education in Portugal is regulated by the Ministry of Education and Science and in Sweden by the Ministry of Education and Research.

In the Portuguese context, the teacher's role is to adopt functions of guidance and support. It should also be noted that in the Decree Law no. 42/2005 (Ministry of Science, Technology and Higher Education 2005), which is underlined in this new perspective, the student should play an active and central role in his/her learning process regarding contact hours, which can take different forms and methods of teaching, or in assessment, in which all activities related to assessment such as contact hours, projects, individual study, field work, etc are to be included. Regarding assessment there may be different methods of student assessment such as oral and written essays, examinations, tests, theses, reports on internships, and fieldwork with continuous assessment, etc.

As an example of a semester in a professional study programme in a Portuguese university, like the Basic Education Programme, the students have to participate in six courses consisting of five ECTS, for a total of 30 ECTS per semester. The plan of courses is decided in advance. The plan for the Basic Education Programme is 
accredited by A3ES (Agency for Assessment and Accreditation of Higher Education 2013). After getting the accreditation the departments offering the programme develop the course plan in detail. The course plan consists of the content of the course, learning goals, assessment, and bibliography. In the section about assessment there is a presentation of when assessment should be carried out during the course, forms it may assume, and on what grounds the assessment is made. During a five-ECTS curricular unit teachers normally two or more different assessment methods to assess student learning may be used. These might include a test, oral presentations, group work, practical work, portfolios, reports, experimental work, projects, etc. Although the assessment methods should be defined in advance by teachers there is flexibility in relation to changing the assessment methods, dates, and weights of assessment.

In Sweden it is the teacher's responsibility to choose the methods as well as the materials. It is expected that students will play an active role, in the laboratory as well as in the seminars. A course may have one or more examinations such as a written examination, oral examination, seminar, thesis, laboratory work, project, reports, essay, etc. However, the examinations can be performed either in groups or individually according to instructions. Assessment is done taking into consideration three basic principles in order to ensure that operations are conducted in a legally sound manner: the principle of predictability, the principle of legality, and the principle of equality/objectivity. Each course has a syllabus and should include a curriculum course level, number of credits, goals, specific entry requirements, and procedures for assessing student performance. In addition there is a study plan document where the work process is further described. The information in the study plan may only be complementary and not replace the curriculum in any way (Swedish Higher Education Authority 2015).

As an example of a semester in a training programme in a Swedish university, such as the Initial Teacher Programme, the students can participate in three courses consisting of 7.5, 7,5 and 15 ECTS, for a total of 30 ECTS per semester. All three courses have a course plan which is decided in advance. The education plan for the Initial Teacher Programme (with specified courses) is decided when the university applies to the Swedish Higher Education Authority to get permission to offer the programme. A course consists of the content of the course, learning goals, assessment and 
bibliography. In the section about assessment there is a presentation of when assessment should be carried out during the course, forms for this to be put into place, and on what grounds the assessment is carried out. During a 7.5 ECTS course it is common that the students have one assignment which they present orally and then hand in a short written report, comprising 1.5 ECTS, and at the end of the course they hand in a written report, comprising 6 ECTS, 7.5 ECTS in total. The teachers and the students cannot negotiate about the assessment time, method or grounds for assessment in the current course plan, but they can add additional formative assessment during the course (Eurydice 2015; Mälardalen University 2015a, b, c). After the course the students assess the course and thereby they can influence the next course and its assessment methods, etc.

\section{Method}

This study is part of a broader piece of research about assessment from different perspectives, such as a literature review (Pereira, Flores and Niklasson 2015) and university teachers' and students' perceptions of assessment. The findings presented in this study are part of the results from questionnaires to students in Portugal and Sweden. The overarching questions of this study are as follows:

1) What issues emerge concerning assessment in the Portuguese and Swedish educational systems?

2) Which main differences can be traced while comparing students in the Portuguese and Swedish educational systems?

3) What implications of the results are there for assessment in higher education?

\section{Participants}

In Portugal, 173 third-year students from different programmes in one public university participate. In Sweden, 72 third-year Swedish students in professional studies in one public university answered the questionnaire. In total, 245 students participated (Table 1): $57 \%$ were female and $43 \%$ male participants in Portugal and $85 \%$ female and $15 \%$ 
male participants in Sweden. The mean age was 20 years in Portugal, and 21 years in Sweden.

Table 1. Participants

\begin{tabular}{llc}
\hline University P & University S & Total \\
\hline 1) Nursing & 1) Nursing & \\
2) Engineering & 2) Engineering & \\
3) Educational Sciences & 3) Educational Sciences & \\
\multicolumn{1}{c}{173} & 72 & 245 \\
\hline
\end{tabular}

\section{Data collection}

Data were obtained through the administration of a survey to the university students in both countries. Ethical considerations, such as information to the students about the context of the study, that the aim was research, and that the answers were confidential was followed in both countries. In Portugal and in Sweden ethical issues were brought up in an accompanying written text in the questionnaire.

In Portugal data were collected between October 2012 and June 2013 in one university. After obtaining the authorisation to conduct the study from the Presidents of Faculties/Schools/Institutes and from the Presidents of the Pedagogical Council of each Faculty/School/Institute, acceptance was obtained from directors of the different programmes. A face-to-face questionnaire was administered by the researcher in Portugal to students attending the third year of the courses.

The study was undertaken during a shorter period in Sweden, for a few months in 2014, and therefore a choice was made to conduct an electronic questionnaire. This option was related to time constraints, since the time was too short to administer the questionnaire face-to-face in the Swedish university. The web questionnaire was designed in Quick Search. The e-mail addresses for the students were obtained from administrators for each programme, after acceptance from responsible people for the different programmes. 
The Portuguese survey was designed based on earlier studies (Pereira and Flores 2012; Flores et al. 2015), and the basic design continued when the survey was carried out in Sweden. As validity check (Lewis-Beck, Bryman and Liao 2004), the questionnaire was sent to a representative from a student association to check that the questions were formulated in a way that was appropriate and relevant for students in Sweden. Minor changes were made, e.g. the word "report" in the Portuguese version was changed to "paper" in the Swedish version.

The questionnaire included three scales with closed-ended questions. The first scale focused on ideas about assessment; statements were formulated and students had to identify the extent to which they associated assessment with these ideas, using $1=$ not at all to $4=$ very much. The second scale related to methods and modes of assessment where the students were asked to identify the frequency of the methods using a scale ranging from $1=$ not at all to $4=$ frequently used. The third scale related to perception of fairness, effectiveness, trust and influence, ranged from $1=$ strongly disagree to $5=$ strongly agree. To analyse the differences the data was transferred to SPSS and a descriptive statistical procedure was undertaken.

\section{Limitations}

The validity of the data can be affected by how the students interpreted the questions and their experience of assessment. Even though the countries have similarities in their education systems, there are also differences. Further, what is written at a policy level is not always carried out in the classroom. The answers are based on students' perceptions and there is no ambition to claim that the results can be generalised. Another limitation is related to the application of the questionnaire, considering that in Portugal the questionnaire was administered face-to-face and in Sweden it was applied electronically. This may have affected the participation rate of the students in the research.

\section{Findings}

This section starts with ideas associated with assessment and is followed by experiences of methods and modes of assessment. It continues with ideas associated with assessment 
and ends with perceptions of assessment. Each question is presented and the most frequent answers are described. This made it easier to find the main tendencies in the answers.

\section{Ideas associated with assessment}

In a comparative perspective (Table 2), for most Portuguese and Swedish students, the ideas most associated with assessment are in general similar. Although Portuguese students associated more to assessment the tests/exams and the Swedish students associated more to assessment the verification of knowledge, other ideas such as grades and learning have similar percentages. However, for Portuguese students fear, injustice and help are associated by most students with assessment, whereas Swedish students associate these ideas less with assessment. Negotiation is the idea least associated with assessment by both student groups.

Table 2. Ideas Associated with Assessment

$\begin{array}{lclc}\text { Tests/exams } & 86,7 \% & \text { Verification of } \\ \text { knowledge } & 90 \% \\ \text { Verification of } & 83,8 \% & \text { Learning } & 87 \% \\ \text { knowledge } & & & \\ \text { Grades } & 81,5 \% & \text { Tests/exams } & 84 \% \\ \text { Anxiety/stress } & 81,5 \% & \text { Grades } & 83 \% \\ \text { Learning } & 81 \% & \text { Reflection } & 82 \% \\ \text { Success } & 75,7 \% & \text { Participation } & 75 \% \\ \text { Reflection } & 65,9 \% & \text { Success } & 74 \% \\ \text { Participation } & 58,4 \% & \text { Anxiety/stress } & 73 \% \\ \text { Injustice } & 56,1 \% & \text { Help } & 48 \% \\ \text { Fear } & 54,9 \% & \text { Imposition } & 45 \% \\ \text { Imposition } & 53,2 \% & \text { Injustice } & 36 \%\end{array}$




\begin{tabular}{lcll}
\hline Help & $52 \%$ & Fear & $36 \%$ \\
Conflict & $34,1 \%$ & Conflict & $36 \%$ \\
Negotiation & $22 \%$ & Negotiation & $35 \%$ \\
\hline
\end{tabular}

\section{Methods and Modes of Assessment Used}

In a comparative perspective (Table 3), it is possible to state that both groups of students consider tests the method most used by teachers to assess them. However, most Portuguese students also identified oral presentations in group, group and individual reports, group and individual practical or experimental work, projects and individual and group written reflections. The Swedish students, in turn, also identified group or individually written papers, oral presentations in group and individual and group written reflections. However, it should be noted that the Portuguese questionnaire had group and individual reports as an option, and did not have group or individually written papers as an option. In contrast, the Swedish questionnaire did not have group or individual reports as an option and had group or individually written papers as an option. In a Swedish context the students perceive that they are asked to perform selfassessment to a higher degree than their Portuguese counterparts. The methods least used by teachers were individual and group portfolio, individual project, individual oral presentations, and oral tests and oral examinations by both student groups. Among the least used methods, in contrast to Portuguese students, the Swedish students consider group or individual practical or experimental work and group project as methods less used. Both groups identify peer assessment as a less-often used mode of assessment.

Table 3. Methods and Modes of Assessment Used

\begin{tabular}{|c|c|c|c|c|}
\hline \multicolumn{2}{|c|}{ Portuguese Students } & \multicolumn{3}{|c|}{ Swedish Students } \\
\hline & $\begin{array}{c}\text { (fairly and } \\
\text { frequently } \\
\text { used) } \%\end{array}$ & & & $\begin{array}{c}\text { (fairly and } \\
\text { frequently } \\
\text { used) } \%\end{array}$ \\
\hline Tests & $90,2 \%$ & Tests & & $98 \%$ \\
\hline $\begin{array}{l}\text { Oral presentations in } \\
\text { group }\end{array}$ & $89,1 \%$ & $\begin{array}{l}\text { Written } \\
\text { papers }\end{array}$ & individual & $84 \%$ \\
\hline
\end{tabular}




\begin{tabular}{|c|c|c|c|}
\hline Reports in group & $83,8 \%$ & Written papers in group & $69 \%$ \\
\hline Individual reports & $74 \%$ & $\begin{array}{l}\text { Oral presentations in } \\
\text { group }\end{array}$ & $66 \%$ \\
\hline Project in group & $67 \%$ & $\begin{array}{l}\text { Individual written } \\
\text { reflections }\end{array}$ & $56 \%$ \\
\hline $\begin{array}{ll}\text { Practical } & \text { or } \\
\text { experimental } & \text { work } \\
\text { group } & \end{array}$ & $65,3 \%$ & $\begin{array}{l}\text { Group written } \\
\text { reflections }\end{array}$ & $50 \%$ \\
\hline $\begin{array}{l}\text { Individual written } \\
\text { reflections }\end{array}$ & $59,5 \%$ & $\begin{array}{l}\text { Oral tests and oral } \\
\text { examinations }\end{array}$ & $48 \%$ \\
\hline $\begin{array}{l}\text { Practical } \\
\text { experimental } \\
\text { individual }\end{array}$ & $52,6 \%$ & $\begin{array}{ll}\text { Practical } & \text { or } \\
\text { experimental work } & \text { in } \\
\text { group } & \end{array}$ & $42 \%$ \\
\hline $\begin{array}{l}\text { Group } \\
\text { reflections }\end{array}$ & $48 \%$ & $\begin{array}{l}\text { The students are asked } \\
\text { to perform self- } \\
\text { assessment }\end{array}$ & $37 \%$ \\
\hline $\begin{array}{l}\text { Individual } \\
\text { presentations }\end{array}$ & $28,9 \%$ & $\begin{array}{lr}\text { Practical } & \text { or } \\
\text { experimental } & \text { work } \\
\text { individual } & \end{array}$ & $36 \%$ \\
\hline Individual project & $26,6 \%$ & Project in group & $35 \%$ \\
\hline Individual portfolio & $23,7 \%$ & Individual project & $26 \%$ \\
\hline $\begin{array}{l}\text { Oral tests and oral } \\
\text { examinations }\end{array}$ & $22 \%$ & $\begin{array}{ll}\text { Individual } & \text { oral } \\
\text { presentations } & \end{array}$ & $21 \%$ \\
\hline $\begin{array}{l}\text { The students are asked } \\
\text { to perform self- } \\
\text { assessment }\end{array}$ & $19,6 \%$ & Portfolios in group & $15 \%$ \\
\hline Portfolios in group & $17,9 \%$ & Individual portfolio & $14 \%$ \\
\hline $\begin{array}{l}\text { The students are asked } \\
\text { to perform peer } \\
\text { assessment }\end{array}$ & $17,9 \%$ & $\begin{array}{l}\text { The students are asked } \\
\text { to perform peer } \\
\text { assessment }\end{array}$ & $12 \%$ \\
\hline
\end{tabular}

\section{Fairness}

In a comparative perspective (Table 4), regarding assessment fairness there are some differences between the two groups. Both groups state that assessment is fairer when teachers use at least two different assessment methods and when it is done individually even if it promotes teamwork. The difference occurs when the Portuguese group rank 
students performing self-assessment high, while it is ranked lower by the Swedish students. On the other hand the Swedish students rank the fairness of assessment when there is self and peer assessment lower than the Portuguese group. Both student groups agree in ranking peer assessment lower. However, although it is the lowest percentage in both cases, in the Portuguese case $40,4 \%$ of students agree and strongly agree that assessment is fairer when there is peer assessment and in the Swedish context only 4\% agree and strongly agree with this item.

Table 4. Assessment Fairness

\begin{tabular}{|c|c|c|c|}
\hline \multicolumn{2}{|c|}{ Portuguese Students } & \multicolumn{2}{|c|}{ Swedish Students } \\
\hline & $\begin{array}{l}\text { (agree and } \\
\text { strongly } \\
\text { agree)\% }\end{array}$ & & $\begin{array}{l}\text { (agree and } \\
\text { strongly } \\
\text { agree)\% }\end{array}$ \\
\hline $\begin{array}{l}\text { Assessment is fairer when } \\
\text { teachers use at least two } \\
\text { different assessment } \\
\text { methods }\end{array}$ & $72,3 \%$ & $\begin{array}{l}\text { Assessment is fairer when } \\
\text { it is done individually even } \\
\text { if it promotes teamwork }\end{array}$ & $70 \%$ \\
\hline $\begin{array}{l}\text { Assessment is fairer when } \\
\text { the students perform a } \\
\text { self-assessment }\end{array}$ & $68,8 \%$ & $\begin{array}{l}\text { Assessment is fairer when } \\
\text { teachers use at least two } \\
\text { different assessment } \\
\text { methods }\end{array}$ & $65 \%$ \\
\hline $\begin{array}{l}\text { Assessment is fairer when } \\
\text { it is done individually even } \\
\text { if it promotes teamwork }\end{array}$ & $68,7 \%$ & $\begin{array}{l}\text { Assessment is fairer when } \\
\text { it includes tests or } \\
\text { examinations }\end{array}$ & $50 \%$ \\
\hline $\begin{array}{l}\text { Assessment is fairer when } \\
\text { there is self- and peer } \\
\text { assessment }\end{array}$ & $53,7 \%$ & $\begin{array}{l}\text { Assessment is fairer when } \\
\text { the students perform a } \\
\text { self-assessment }\end{array}$ & $43 \%$ \\
\hline $\begin{array}{l}\text { Assessment is fairer when } \\
\text { it includes tests or } \\
\text { examinations }\end{array}$ & $49,8 \%$ & $\begin{array}{l}\text { Portfolios, projects or } \\
\text { reflections allow a fairer } \\
\text { assessment }\end{array}$ & $39 \%$ \\
\hline $\begin{array}{l}\text { Tests or examinations } \\
\text { allow a fairer assessment }\end{array}$ & $48 \%$ & $\begin{array}{l}\text { Tests or examinations } \\
\text { allow a fairer assessment }\end{array}$ & $34 \%$ \\
\hline $\begin{array}{l}\text { Portfolios, projects or } \\
\text { reflections allow a fairer } \\
\text { assessment }\end{array}$ & $40,4 \%$ & $\begin{array}{l}\text { Assessment is fairer when } \\
\text { there is self- and peer } \\
\text { assessment }\end{array}$ & $15 \%$ \\
\hline $\begin{array}{l}\text { Assessment is fairer when } \\
\text { there is peer assessment }\end{array}$ & $40,4 \%$ & $\begin{array}{l}\text { Assessment is fairer when } \\
\text { there is peer assessment }\end{array}$ & $4 \%$ \\
\hline
\end{tabular}




\section{Effectiveness of Assessment}

In a comparative perspective (Table 5), Portuguese students ranked higher assessment as more effective when it encourages applying knowledge in real contexts and Swedish students ranked assessment highest as allowing them to improve technical or scientific skills. Both students groups also agree and strongly agree that assessment contributes to the deepening of learning, allowing them to develop technical and soft skills simultaneously. The difference is that the Portuguese students were in greater agreement in their ranking of these items than the Swedish students. As for the total group, both Portuguese and Swedish students considered tests the least effective method.

Table 5. Assessment Effectiveness

\begin{tabular}{|c|c|c|c|}
\hline \multicolumn{2}{|c|}{ Portuguese students } & \multicolumn{2}{|l|}{ Swedish students } \\
\hline & $\begin{array}{l}\text { (agree and } \\
\text { strongly } \\
\text { agree)\% }\end{array}$ & & $\begin{array}{c}\text { (agree and } \\
\text { strongly } \\
\text { agree)\% }\end{array}$ \\
\hline $\begin{array}{l}\text { Assessment is more } \\
\text { effective when it } \\
\text { encourages applying } \\
\text { knowledge in real contexts }\end{array}$ & $97,7 \%$ & $\begin{array}{l}\text { Assessment is more } \\
\text { effective when it allows } \\
\text { improvement of technical } \\
\text { or scientific skills }\end{array}$ & $86 \%$ \\
\hline $\begin{array}{l}\text { Assessment is more } \\
\text { effective when it allows } \\
\text { improvement of technical } \\
\text { or scientific skills }\end{array}$ & $96 \%$ & $\begin{array}{l}\text { Assessment is more } \\
\text { effective when it } \\
\text { contributes to the } \\
\text { deepening of learning }\end{array}$ & $80 \%$ \\
\hline $\begin{array}{lcr}\text { Assessment } & \text { is more } \\
\text { effective } & \text { when } & \text { it } \\
\text { contributes } & \text { to the }\end{array}$ & $94,8 \%$ & \begin{tabular}{lrr} 
Assessment & is & more \\
effective & when & it \\
encourages & \multicolumn{2}{c}{ applying }
\end{tabular} & $76 \%$ \\
\hline deepening of learning & & knowledge in real contexts & \\
\hline $\begin{array}{l}\text { Assessment is more } \\
\text { effective when it allows } \\
\text { simultaneous improvement } \\
\text { of technical and soft skills }\end{array}$ & $89 \%$ & $\begin{array}{l}\text { Assessment is more } \\
\text { effective when it allows } \\
\text { simultaneous improvement } \\
\text { of technical and soft skills }\end{array}$ & $62 \%$ \\
\hline
\end{tabular}




\begin{tabular}{llllll}
\hline Portfolios, projects or & $44,5 \%$ & Portfolios, projects or & $41 \%$ \\
reflections allow a more & & reflections allow a more & \\
effective assessment & & effective assessment & \\
Tests allow a more & $40,4 \%$ & $\begin{array}{l}\text { Tests allow a more } \\
\text { effective assessment }\end{array}$ & & effective assessment & \\
\end{tabular}

\section{Trust and Assessment}

In a comparative perspective (Table 6), both student groups agree or strongly agree that they felt more confident when they were assessed by a method requiring active participation in the task, even though there is more than $10 \%$ difference. Portuguese students agreed to a higher degree that they felt confident with assessment methods other than tests, compared to the Swedish students. The lowest ranking concerned tests, that is, both groups have less trust in tests.

Table 6. Trust and Assessment

\begin{tabular}{|c|c|c|c|}
\hline \multicolumn{2}{|c|}{ Portuguese Students } & \multicolumn{2}{|l|}{ Swedish Students } \\
\hline & $\begin{array}{l}\text { (agree and } \\
\text { strongly } \\
\text { agree)\% }\end{array}$ & & $\begin{array}{l}\text { (agree and } \\
\text { strongly } \\
\text { agree)\% }\end{array}$ \\
\hline $\begin{array}{l}\text { The students felt more } \\
\text { confident when they are } \\
\text { assessed by assessment } \\
\text { methods that actively } \\
\text { participated in the tasks }\end{array}$ & $78,1 \%$ & $\begin{array}{l}\text { The students felt more } \\
\text { confident when they are } \\
\text { assessed by assessment } \\
\text { methods that actively } \\
\text { participated in the tasks }\end{array}$ & $63 \%$ \\
\hline $\begin{array}{l}\text { The students felt more } \\
\text { confident when they are } \\
\text { assessed by a method that is } \\
\text { not tests or exams }\end{array}$ & $45,7 \%$ & $\begin{array}{l}\text { The students felt more } \\
\text { confident when they are } \\
\text { assessed by a method that is } \\
\text { not tests or exams }\end{array}$ & $38 \%$ \\
\hline $\begin{array}{l}\text { The students felt more } \\
\text { confident when they are } \\
\text { assessed by tests }\end{array}$ & $34,7 \%$ & $\begin{array}{l}\text { The students felt more } \\
\text { confident when they are } \\
\text { assessed by tests }\end{array}$ & $29 \%$ \\
\hline
\end{tabular}


In a comparative perspective (Table 7), both student groups agree or strongly agree that it is up to the teacher to decide the assessment methods. When the assessment is carried out there are differences between the two groups. Whereas in the Portuguese context assessment is perceived to take place throughout the semester, including every time the student performs a task, in the Swedish context assessment is perceived to take place at the end of the semester and to a lower degree every time the student performs a task.

Table 7. Influence and Time for Assessment

\begin{tabular}{|c|c|c|c|}
\hline \multicolumn{2}{|c|}{ Portuguese Students } & \multicolumn{2}{|c|}{ Swedish Students } \\
\hline & $\begin{array}{c}\text { (agree and } \\
\text { strongly } \\
\text { agree)\% }\end{array}$ & & $\begin{array}{c}\text { (agree and } \\
\text { strongly } \\
\text { agree)\% }\end{array}$ \\
\hline $\begin{array}{l}\text { The assessment } \\
\text { methodology of the course } \\
\text { is decided only by the } \\
\text { teacher }\end{array}$ & $80,9 \%$ & $\begin{array}{l}\text { The assessment } \\
\text { methodology of the course } \\
\text { is decided only by the } \\
\text { teacher }\end{array}$ & $62 \%$ \\
\hline $\begin{array}{l}\text { The assessment takes place } \\
\text { throughout the semester }\end{array}$ & $44,5 \%$ & $\begin{array}{l}\text { The assessment takes place } \\
\text { at the end of the semester }\end{array}$ & $61 \%$ \\
\hline $\begin{array}{l}\text { The assessment takes place } \\
\text { every time the students } \\
\text { perform a task }\end{array}$ & $44,5 \%$ & $\begin{array}{l}\text { The assessment takes place } \\
\text { every time the students } \\
\text { perform a task }\end{array}$ & $37 \%$ \\
\hline $\begin{array}{l}\text { The assessment takes place } \\
\text { at the end of the semester }\end{array}$ & $43,4 \%$ & $\begin{array}{l}\text { The assessment takes place } \\
\text { throughout the semester }\end{array}$ & $32 \%$ \\
\hline $\begin{array}{l}\text { The assessment } \\
\text { methodology of the course }\end{array}$ & $16,8 \%$ & $\begin{array}{l}\text { The assessment } \\
\text { methodology of the course }\end{array}$ & $2 \%$ \\
\hline $\begin{array}{l}\text { was negotiated and } \\
\text { discussed with the students }\end{array}$ & & $\begin{array}{l}\text { was negotiated and } \\
\text { discussed with the students }\end{array}$ & \\
\hline
\end{tabular}

Differences were also found regarding the knowledge area in both countries. In the Portuguese context differences emerge regarding the ideas associated with assessment, the assessment methods used, fairness, effectiveness and trust in assessment. The students who attend the Engineering programme associated most with assessment the 
verification of knowledge, test and learning; the students who attend Nursing programme associated most with assessment the tests, learning and anxiety/stress; and the students who attend Educational Sciences programme associated most with assessment the verification of knowledge, grades and anxiety/stress (see table 8). Anxiety/stress as a negative idea is higher in Nursing and Educational Sciences programmes and learning as a positive idea is higher in Engineering and Nursing programmes. The idea of conflict is ranked in a higher level by students who attend Nursing programme than students in Engineering and Educational Sciences programmes. The ideas less associated with assessment are conflict and negotiation in Engineering and Educational Sciences programmes and conflict and help in Nursing programme.

Table 8. Ideas Associated with Assessment between programmes

\begin{tabular}{|c|c|c|c|}
\hline \multirow[t]{2}{*}{$\begin{array}{l}\text { Ideas associated with } \\
\text { assessment }\end{array}$} & \multirow{2}{*}{$\begin{array}{l}\text { Engineering } \\
\text { (fairly and very } \\
\text { much\%) }\end{array}$} & \multirow{2}{*}{\begin{tabular}{l}
\multicolumn{1}{c}{ Nursing } \\
(fairly and very \\
much\%)
\end{tabular}} & \multirow{2}{*}{$\begin{array}{l}\text { Educational } \\
\text { Sciences } \\
\text { (fairly and very } \\
\text { much\%) }\end{array}$} \\
\hline & & & \\
\hline Tests/exams & $86,6 \%$ & $88,1 \%$ & $83,4 \%$ \\
\hline Verification & $86,6 \%$ & $81,6 \%$ & $93,3 \%$ \\
\hline \multicolumn{4}{|l|}{ knowledge } \\
\hline Grades & $74,6 \%$ & $82,9 \%$ & $93,3 \%$ \\
\hline Anxiety/stress & $74,6 \%$ & $85,6 \%$ & $86,6 \%$ \\
\hline Learning & $80,6 \%$ & $86,8 \%$ & $66,7 \%$ \\
\hline Success & $68,6 \%$ & $82,9 \%$ & $73,3 \%$ \\
\hline Reflection & $52,2 \%$ & $73,7 \%$ & $76,7 \%$ \\
\hline Participation & $55,2 \%$ & $60,5 \%$ & $60 \%$ \\
\hline Injustice & $52,2 \%$ & $59,2 \%$ & $56,7 \%$ \\
\hline Fear & $34,4 \%$ & $68,9 \%$ & $66,7 \%$ \\
\hline Imposition & $49,3 \%$ & $57,9 \%$ & $50 \%$ \\
\hline Help & $55,3 \%$ & $46 \%$ & $60 \%$ \\
\hline Conflict & $20,9 \%$ & $47,3 \%$ & $30 \%$ \\
\hline Negotiation & $23,9 \%$ & $17,2 \%$ & $30 \%$ \\
\hline
\end{tabular}


Regarding assessment methods students who attend the Engineering programme consider the oral presentations in group the method most used; the students who attend the Nursing programme consider the tests the method most used; and all the students who attend Educational Sciences programme consider the individual reflections the method most used to assess them (see table 9). The use of the project in group is higher in Engineering and in Educational Sciences than in Nursing. The use of tests is lower in Educational Sciences than in Nursing and Engineering. The individual project is most used in Engineering than in Educational Sciences and Nursing programmes. The portfolios, individual and in group, are also most used in Educational Sciences programme than in other programmes. The least used methods are the individual presentations and portfolios in Engineering programme, the portfolio, individual and in group, in Nursing and the individual oral presentations and oral tests in Educational Sciences. Also, few students consider that are asked to perform self and peer assessment in the three programmes (see Table 9. Methods and Modes of Assessment Used between programmes).

\begin{tabular}{|c|c|c|c|}
\hline Assessment methods & Engineering & Nursing & $\begin{array}{c}\text { Educational } \\
\text { Sciences }\end{array}$ \\
\hline & $\begin{array}{c}\text { (fairly and } \\
\text { frequently } \\
\text { used\%) }\end{array}$ & $\begin{array}{c}\text { (fairly and } \\
\text { frequently } \\
\text { used\%) }\end{array}$ & $\begin{array}{c}\text { (fairly and } \\
\text { frequently } \\
\text { used\%) }\end{array}$ \\
\hline Tests & $87 \%$ & $98,7 \%$ & $53,3 \%$ \\
\hline $\begin{array}{l}\text { Oral presentations in } \\
\text { group }\end{array}$ & $89,5 \%$ & $85,5 \%$ & $96,7 \%$ \\
\hline Reports in group & $86,6 \%$ & $82,9 \%$ & $80 \%$ \\
\hline Individual reports & $55,3 \%$ & $89,5 \%$ & $76,6 \%$ \\
\hline Project in group & $86,5 \%$ & $39,5 \%$ & $93,3 \%$ \\
\hline $\begin{array}{l}\text { Practical or experimental } \\
\text { work in group }\end{array}$ & $70,1 \%$ & $53,9 \%$ & $83,3 \%$ \\
\hline $\begin{array}{l}\text { Individual written } \\
\text { reflections }\end{array}$ & $23,9 \%$ & $75 \%$ & $100 \%$ \\
\hline $\begin{array}{l}\text { Practical or experimental } \\
\text { work individual }\end{array}$ & $53,7 \%$ & $47,4 \%$ & $63,4 \%$ \\
\hline Group written reflections & $34,4 \%$ & $54 \%$ & $63,3 \%$ \\
\hline
\end{tabular}




\begin{tabular}{lccc}
\hline Individual $\begin{array}{l}\text { oral } \\
\text { presentations }\end{array}$ & $16,4 \%$ & $38,2 \%$ & $33,3 \%$ \\
$\begin{array}{l}\text { Individual project } \\
\text { Individual portfolio }\end{array}$ & $70,7 \%$ & $34,2 \%$ & $36,6 \%$ \\
Oral tests and oral & $16,4 \%$ & $19,7 \%$ & $50 \%$ \\
examinations & $23,9 \%$ & $27,6 \%$ & $36,6 \%$ \\
The students are asked to & $7,5 \%$ & & \\
perform self-assessment & & $27,7 \%$ & $26,7 \%$ \\
Portfolios in group & $16,4 \%$ & $3,9 \%$ & $53,3 \%$ \\
The students are asked to & $32,9 \%$ & $7,9 \%$ & $10 \%$ \\
perform peer assessment & & & \\
\hline
\end{tabular}

Regarding the assessment fairness, the majority of the students attending Educational Sciences programme consider that portfolios, projects or reflections and peer assessment allow a fairer assessment, in contrast to the opinion of students attending programmes of Engineering and Nursing (see table 10). Also, most of the students attending Engineering and Nursing consider that assessment is fairer when it includes tests, in contrast to the opinion of the students attending Educational Sciences.

Table 10. Assessment Fairness between programmes

\begin{tabular}{lccc}
\hline \multicolumn{1}{c}{ Assessment Fairness } & Engineering & Nursing & $\begin{array}{c}\text { Educational } \\
\text { Sciences }\end{array}$ \\
\hline & $\begin{array}{c}\text { (agree and } \\
\text { strongly agree } \\
\text { \%) }\end{array}$ & $\begin{array}{c}\text { (agree and } \\
\text { strongly agree }\end{array}$ & $\begin{array}{c}\text { (agree and } \\
\text { strongly agree }\end{array}$ \\
& & $\%$ \%) & \%) \\
\hline $\begin{array}{l}\text { Assessment is fairer when } \\
\text { includes tests or }\end{array}$ & $55,2 \%$ & $56,6 \%$ & $20 \%$ \\
examinations & & & \\
Tests or examinations & $52,2 \%$ & $56,6 \%$ & $16,7 \%$ \\
allow a fairer assessment & & & \\
\hline
\end{tabular}




\begin{tabular}{llcc}
\hline $\begin{array}{l}\text { Portfolios, projects or } \\
\text { reflections allow a fairer }\end{array}$ & $35,8 \%$ & $35,5 \%$ & $63,3 \%$ \\
assessment & & & \\
Assessment is fairer when & $32,9 \%$ & $42,1 \%$ & $53,4 \%$ \\
there is peer assessment & & & \\
\end{tabular}

This research also found that most students attending Educational Sciences have the opinion that portfolios, projects or reflections allow a more effective assessment, in contrast to other programmes (see table 11). Moreover, the students attending Engineering and Nursing ranked highest that tests allow a more effective assessment than the students attending Educational Sciences.

Table 11. Assessment Effectiveness between programmes

\begin{tabular}{lccc}
\hline \multicolumn{1}{c}{ Assessment Effectiveness } & Engineering & Nursing & $\begin{array}{c}\text { Educational } \\
\text { Sciences }\end{array}$ \\
\hline & $\begin{array}{c}\text { (agree and } \\
\text { strongly agree } \\
\mathbf{\%})\end{array}$ & $\begin{array}{c}\text { (agree and } \\
\text { strongly agree } \\
\text { \%) }\end{array}$ & $\begin{array}{c}\text { (agree and } \\
\text { strongly agree } \\
\text { \%) }\end{array}$ \\
\hline $\begin{array}{l}\text { Portfolios, projects or } \\
\text { reflections allow a more } \\
\text { effective assessment }\end{array}$ & $\begin{array}{c}41,7 \% \\
38,1 \%\end{array}$ & $66,7 \%$ \\
$\begin{array}{l}\text { Tests allow a more effective } \\
\text { assessment }\end{array}$ & $44,8 \%$ & & \\
\hline
\end{tabular}

Regarding trust and assessment findings show that students attending Educational Sciences felt more confident when they are assessed by a method that is not test or exam (see table 12). Also, the students attending Engineering and Nursing felt more confident when they are assessed through tests than students attending Educational Sciences.

Table 12. Trust and Assessment between programmes 


\begin{tabular}{lccc}
\hline Trust and Assessment & Engineering & Nursing & $\begin{array}{c}\text { Educational } \\
\text { Sciences }\end{array}$ \\
\hline & $\begin{array}{c}\text { (agree and } \\
\text { strongly agree } \\
\text { \%) }\end{array}$ & $\begin{array}{c}\text { (agree and } \\
\text { strongly agree } \\
\text { \%o) }\end{array}$ & $\begin{array}{c}\text { (agree and } \\
\text { strongly } \\
\text { agree \%) }\end{array}$ \\
$\begin{array}{l}\text { The students felt more confident } \\
\text { when they are assessed by a } \\
\text { method that is not tests or exams } \\
\begin{array}{l}\text { The students felt more confident } \\
\text { when they are assessed by tests }\end{array}\end{array} \quad 38,8 \%$ & $36,9 \%$ & $80 \%$ \\
\hline
\end{tabular}

In the Swedish context, some differences emerged between Nursing and Educational Sciences programmes regarding ideas associated with assessment, assessment methods, fairness and effectiveness of assessment. The ideas most associated with assessment by students attending Nursing programme are verification of knowledge, reflection and learning (see Table 13). On the other hand, all of the students attending Educational Sciences programme associated with assessment anxiety, followed by tests and grades. Also, the students from Educational Sciences ranked higher fear than students attending the Nursing programme.

Table 13. Ideas Associated with Assessment between programmes

\begin{tabular}{lcc}
\hline $\begin{array}{l}\text { Ideas associated } \\
\text { with assessment }\end{array}$ & Nursing & $\begin{array}{c}\text { Educational } \\
\text { Sciences }\end{array}$ \\
\hline & $\begin{array}{c}\text { (fairly and very } \\
\text { much \%) }\end{array}$ & $\begin{array}{c}\text { (fairly and very } \\
\text { much \%) }\end{array}$ \\
\hline Tests/exams & $\mathbf{8 1 , 6 \%}$ & $\mathbf{9 0 , 9 \%}$ \\
Verification of & $\mathbf{9 2 , 5 \%}$ & $\mathbf{7 5 \%}$ \\
knowledge & & \\
Grades & $\mathbf{8 0 , 5 \%}$ & $\mathbf{8 0 \%}$ \\
Anxiety/stress & $\mathbf{6 9 , 3 \%}$ & $\mathbf{1 0 0 \%}$ \\
Learning & $\mathbf{8 9 , 7 \%}$ & $\mathbf{7 5 \%}$ \\
Success & $\mathbf{7 8 , 3 \%}$ & $\mathbf{5 0 \%}$ \\
\hline
\end{tabular}




\begin{tabular}{lcc}
\hline Reflection & $\mathbf{9 2 , 1 \%}$ & $\mathbf{5 8 , 4 \%}$ \\
Participation & $\mathbf{8 4 , 2 \%}$ & $\mathbf{6 6 , 6 \%}$ \\
Injustice & $\mathbf{3 2 , 4 \%}$ & $\mathbf{5 8 , 3 \%}$ \\
Fear & $\mathbf{2 7 \%}$ & $\mathbf{7 5 \%}$ \\
Imposition & $\mathbf{4 3 , 2 \%}$ & $\mathbf{4 1 , 7 \%}$ \\
Help & $\mathbf{4 1 , 7 \%}$ & $\mathbf{5 0 \%}$ \\
Conflict & $\mathbf{3 5 , 1 \%}$ & $\mathbf{4 1 , 7 \%}$ \\
Negotiation & $\mathbf{3 7 , 8 \%}$ & $\mathbf{2 5 \%}$ \\
\hline
\end{tabular}

Regarding assessment methods all the students attending Nursing programme ranked the tests the method most used, followed by paper in group and individual (see table 14). The students attending the Educational Sciences programme ranked the tests, the individual presentations and the paper individual the most used methods. Also, students from Nursing programme consider the oral presentations in group and portfolio in group the least method used and the students attending Educational Sciences programme identify the portfolio in group and individual the less methods used. The students from Nursing programme have higher means in paper in group than students attending Educational Sciences. None of the students from Educational Sciences are asked to perform peer assessment.

Table 14. Methods and Modes of Assessment used between programmes

\begin{tabular}{lcc}
\hline \multicolumn{1}{c}{ Assessment methods } & Nursing & Educational Sciences \\
\hline & $\begin{array}{c}\text { (fairly and frequently } \\
\text { used } \%)\end{array}$ & $\begin{array}{c}\text { (fairly and frequently } \\
\text { used\%) }\end{array}$ \\
\hline Tests & $100 \%$ & $90,9 \%$ \\
Oral presentations in group & $16,2 \%$ & $25 \%$ \\
Paper in group & $69,4 \%$ & $14,2 \%$ \\
Paper individual & $68,4 \%$ & $71,4 \%$ \\
Project in group & $36,1 \%$ & $8,3 \%$ \\
Practical or experimental work in & $41,7 \%$ & $25 \%$ \\
\hline
\end{tabular}


group

Individual written reflections

$64,9 \%$

$16,7 \%$

Practical or experimental work

$48,6 \%$

$25 \%$

individual

Group written reflections

$64,9 \%$

$41,7 \%$

Individual oral presentations

$57,9 \%$

$83,3 \%$

Individual project

$39,4 \%$

$8,3 \%$

Individual portfolio

$22,2 \%$

$0 \%$

Oral tests and oral examinations

$45,9 \%$

$62,7 \%$

The students are asked to perform

$37,6 \%$

$40 \%$

self-assessment

Portfolios in group

$19,5 \%$

$0 \%$

The students are asked to perform

$13,3 \%$

$0 \%$

peer assessment

Regarding the assessment fairness some differences emerged between the two programmes (see table 15). Nursing students ranked in a higher level the assessment fairness when it includes tests or examinations. Also, most of the students attending Educational Sciences ranked highest the fact of portfolios, projects and reflections allowing a fairer assessment.

Table 15. Assessment Fairness between programmes

Assessment Fairness

Nursing

Educational Sciences

(agree and strongly

(agree and strongly

agree \%)

agree \%)

Assessment is fairer when it includes

$52,9 \%$

$25 \%$

tests or examinations

Portfolios, projects or reflections allow

$37,5 \%$

$50 \%$

a fairer assessment 
In regard to assessment effectiveness and in contrast to the Educational Sciences students, most of Nursing students agree and strongly agree that tests allow a more effective assessment (see table 16)

Table 16. Assessment Effectiveness between programmes

\begin{tabular}{|c|c|c|}
\hline Assessment Effectiveness & Nursing & Educational Sciences \\
\hline & $\begin{array}{c}\text { (agree and strongly } \\
\text { agree } \%)\end{array}$ & $\begin{array}{c}\text { (agree and strongly } \\
\text { agree } \% \text { ) }\end{array}$ \\
\hline $\begin{array}{l}\text { Tests allow a more effective } \\
\text { assessment }\end{array}$ & $61,2 \%$ & $25 \%$ \\
\hline
\end{tabular}

\section{Discussion}

The ideas most associated with assessment are, in general, related to four main aspects: assessment itself; learning; positive ideas; and negative ideas. Flores et al. (2015) also found that students associated positive, negative, and neutral ideas with assessment. Learning is associated with assessment as a positive issue; unfairness, fear and conflict as negative; and tests, examinations and grades as neutral. However, positive and neutral ideas are associated more with assessment than negative ones, with the exception of anxiety. These results show how significant the process of assessment itself is from the student perspective. In fact, Biggs (2003) explained that students' perceptions of assessment will affect their involvement in the learning process. He asserts that while in the assessment process cycle, teachers first see the objectives, learning outcomes and learning activities and only then look at assessment, students see assessment first of all and only afterwards look at learning activities and the outcomes. This may explain why assessment influences how students learn.

From a student perspective the assessment method most often used is the written test or exam. Besides the test, the assessment methods most used are those that promote teamwork such as oral presentations in groups, practical work in groups, and projects in groups. These are methods which have expanded (Sambell et al. 1997) over the years. There are methods that promote work in groups follow the economic and social norms which mandate that education systems form a citizen who is "autonomous, who is a 
self-regulated learner, capable of communicating and cooperating with others" (Birenbaum 1996:4). Furthermore, these methods allow "the integration of assessment, teaching and learning" (Sambell et al. 1997:352).

Whatever the method, the students reported both negative and positive feelings regarding assessment. Negative feelings were reported as anxiety, stress, and fear. Earlier studies (Craddock and Mathias 2009; Race 1995) indicated that these negative feelings influence and reduce the academic performance of students. From this study, there is evidence that students feel more confident when being assessed through methods in which they participate actively in the tasks and feel less confident when they are assessed through a test. These findings may be related to the levels of stress and anxiety that students are exposed to when taking a test. When they are assessed by methods in which they participate actively in the tasks the students do not have the pressure of memorisation, or as limited a time to do the task as when they perform a test.

One of the alternative assessment modes, self and peer assessment, resulted in answers which show both positive and negative perceptions among students and also a difference in experience. In a comparative perspective, most of the Portuguese students consider that assessment is fairer when there is self and peer assessment. On the contrary, the Swedish students do not consider assessment fairer when there is self and peer assessment. These results demonstrate that Swedish students had less positive experience with the fairness of these assessment practices. The less positive result from the Swedish students can be understood considering the relationship between students which, depending on the proximity, can benefit some to the detriment of others and therefore result in an unfair process. Students can assess peers on the basis of friendship and when students self-assess they may also overestimate their work, leading to an unfair process.

On the other hand, Portuguese students are seldom asked to perform self-assessment by teachers, less than the Swedish students, and they are not used to the possibility of autonomy and responsibility (Lew et al. 2009), and the chance to support collaborative work (Segers and Dochy 2001). In accordance with an individual perspective, for the assessment process to be fair, students recognise that teachers should use at least two 
different assessment methods. However, in this particular case, the perceptions of both groups of students may be influenced by the structure of the credit system of each course in each programme. Accordingly, some of the programmes selected in the Portuguese and Swedish context have different credit structures. For instance, the Portuguese courses are typically of 5 credits each, resulting on a total of 30 credits and it is expressed by the Portuguese higher education system to be used at least two assessment methods regardless of the course credits. In the Swedish context, the credit values are approximately between 7.5 and 15 credits, resulting in a total of 30 credits being also common the use of two assessment methods as the assignment and the written report. Therefore, these differences in credit structure may influence students' perceptions in both countries. Also, for the assessment process to be fair students recognise the importance of an individual assessment even if the work is performed in groups. Thus, the individual assessment allows for the contribution of each student to the group work, individualising and distinguishing the work and the effort of each student.

Students state that the assessments are only decided by the teachers and not discussed with them. In general, considering these results it is possible to see that there is little negotiation about assessment and moments of assessment. The negotiation of assessment is an important aspect as it motivates the students and they feel responsible and part of the process. Despite this finding, most of Portuguese and Swedish students associated with assessment the idea of participation. Students say they do not participate in the negotiation of assessment nor on their self assessment nor in the assessment of colleagues. Thus, this finding may reveal some tensions in their perceptions.

For most students, assessment takes place during the semester. However, in a comparative perspective between Swedish and Portuguese students, most of the Swedish students consider that assessment takes place at the end of the semester, while most of the Portuguese students consider that assessment takes place throughout the semester. Continuous assessment during the semester benefits learning and promotes a more regulated, fairer and effective assessment. From the results it appears that self and peer assessment are less commonly used.

The emerging differences by programmes in both countries reveal that students associated with assessment different ideas, different methods to assess them are used and the effectiveness, fairness and trust of assessment has variations depending on the 
knowledge area. In the Portuguese context the students attending Nursing and Educational Sciences ranked in higher level negative ideas such as anxiety/stress than students attending Engineering. Also, the idea of conflict is ranked in a higher level by students who attend Nursing programme than other programmes. The students attending Educational Sciences see assessment as fairer and effective when projects, portfolios and reflections are used being these methods the most used in this area. In contrast, students attending Engineering and Nursing programmes ranked in a higher level that assessment is fairer and effective when tests are used being these methods the most used to assess them by teachers in this areas. However, the project in group is most used in Engineering and in Educational Sciences than in Nursing.

In the Swedish context, the students attending Educational Sciences associated with assessment more negative ideas such as anxiety/stress and fear than students who attend Nursing who associated more with assessment positive ideas such as reflection and learning. The methods most used in Educational Sciences programme are methods that are performed individually than in Nursing programme. However, the test is the method most used in both programmes. On one hand, the students' attending the Educational Sciences see assessment as fairer when it includes portfolios, projects and reflections. On the other hand, the students attending Nursing see assessment as fairer and effective when it includes tests.

Overall, the Educational Sciences programme presents more differences regarding assessment methods used and perceptions of fairness and the effectiveness of methods than in other programmes. Furthermore, the students attending the programme of Educational Sciences associated most negative ideas with assessment. There are some studies regarding the differences between the assessment methods and knowledge areas (Lueddeke 2003; Goubeaud and Yan 2004; Lindblom-Ylanne et al 2006; Yankowitz and Hahs-Vaughn 2007; Goubeaud 2010; Webber 2012). However, this study suggests further research on fairness and effectiveness of assessment and ideas associated with assessment taking into account the knowledge areas.

In a comparative perspective, both Portugal and Sweden have signed the Bologna Declaration (1999), but also continued to have a national design for higher education. The results show that there are minor differences, for example in the methods used, time of assessment, and who is carrying out the assessment. It can be an effect of the education system and its need to have a safe legal status. At the same time there seems to be room for agency concerning the professionals, but less in relation to the students. 
Their influence seems to be low in both countries. As earlier studies have emphasised, the need for active students and the need for them to show an interest in "assessment literacy," (FALTA REFERENCIA) needs to be explored further, which might be related to the use of self and peer assessment. Teachers are not always using these modes of assessment and the students do not always seem to "trust" these methods. This indicates that they need to be further developed and validated. The implications for assessment in higher education are that national autonomy for education and professionals in higher education is maintained, and that it is possible to further develop learner-oriented assessment. The modes of self and peer assessment in particular seem to be an issue to discuss in the future. Particularly, it would be important to understand why these modes of assessment are not often used in higher education settings and to what extent this might influence the assessment process and enhance students' learning.

\section{References}

Agency for Assessment and Accreditation of Higher Education (2013). Manual de Avaliação [Evaluation Manual], version 1.1. http://www.a3es.pt/pt/acreditacao-eauditoria/manual-de-avaliacao/manual-de-avaliacao. Accessed 2 November 2014.

Biggs, J. (2003). Teaching for Quality Learning at University. Buckingham: SHRE Open University Press.

Birenbaum, M. (1996). Assessment 2000: towards a pluralistic approach to assessment. In M. Birenbaum \& F. Dochy (Eds.), Alternatives in assessment of achievements, learning processes and prior knowledge (pp. 3-30). Boston: Kluwer.

Birenbaum, M. \& Feldman, R. (1998). Relationships between learning patterns and attitudes towards two assessment formats. Educational Research, 40 (1), 90-97.

Bologna Declaration. (1999). Joint Declaration of the European Ministers of Education. Bologna: The European Higher Education Area.

Boud, D. (1990). Assessment and the promotion of academic values. Studies in Higher Education, 15 (1), 1-11. 
Boud, D. (1995). Assessment and Learning: contradictory or complementary? In P. Knight (Ed.), Assessment for learning in higher education (pp. 35-48). London: Kogan Page Limited.

Boud, D., \& Falchikov, N. (2006). Aligning assessment with long-term learning. Assessment and Evaluation in Higher Education, 31 (4), 399-413.

Brew, C., Riley, P., \& Walta, C. (2009). Education students and their teachers: comparing views on participative assessment practices. Assessment and Evaluation in Higher Education, 34 (6), 641-657.

Brown, S. \& Knight, P. (1994). Assessing learners in higher education. London: Kogan Page.

Carless, D. (2015). Exploring learning-oriented assessment processes. Higher Education, 69 (6), 963-976.

Craddock, D. \& Mathias, H. (2009). Assessment options in higher education, Assessment and Evaluation in Higher Education, 34 (2), 127-140.

Dochy, F., Segers, M., \& Sluijsmans, D. (1999). The use of self-, peer and coassessment in higher education: a review. Studies in Higher Education, 24 (3), 31-50.

Duncan, T., \& Buskirk-Cohen, A. (2011). Exploring Learner-Centered Assessment: A Cross-Disciplinary Approach. International Journal of Teaching and Learning in Higher Education, 23 (2), 246-259.

Entwistle, N. J. (1991). Approaches to learning and perceptions of the learning environment. Introduction to the special issue. Higher Education, 22 (3), 201-204.

Entwistle, N. J., \& Entwistle, A. (1991). Contrasting forms of understanding for degree examinations: the student experience and its implications. Higher Education, 22 (3), 205-227. 
Eurydice (2015). National Education Systems, Higher Education. https://webgate.ec.europa.eu/fpfis/mwikis/eurydice/index.php/Sweden:Higher_Educatio n. Acessed 13 January 2015.

Fletcher, R., Meyer, L., Anderson, H., Johnston, P., \& Rees, M. (2012). Faculty and Students Conceptions of Assessment in Higher Education. Higher Education, 64 (1), $120-133$

Flores, M. A., Veiga Simão, A., Barros, A., \& Pereira, D. (2015). Perceptions of effectiveness, fairness and feedback of assessment methods: a study in higher education. Studies in Higher Education, 40 (9), 1523-1534.

Gibbs, G., \& Simpson, C. (2004). Does your assessment support your students' learning? Journal of Learning and Teaching in Higher Education, 1:3-31.

Gilles, J. L., Detroz, P., \& Blais, J. G. (2011). An international online survey of the practices and perceptions of higher education professors with respect to the assessment of learning in the classroom. Assessment and Evaluation in Higher Education, 36 (6), 719-733.

Goubeaud, K. (2010). How is Science Learning Assessed at the Postsecondary Level? Assessment and Grading Practices in College Biology, Chemistry and Physics. Journal of Science Education and Technology, 19 (3): 237-245.

Goubeaud, K., \& Yan, W. (2004). Teacher educators' teaching methods, assessments, and grading: a comparison of higher education faculty's instructional practices. The Teacher Educator, 40 (1), 1-16.

Hernández, R. (2012). Does continuous assessment in higher education support student learning? Higher Education, 64 (4), 489-502.

Huba, M.E., \&. Freed, J. (2000). Learner-centered Assessment on College Campuses: Shifting the Focus from Teaching to Learning. Boston, MA: Allyn and Bacon. 
Lew, M., Alwis, W., \& Schmidt, H. (2009). Accuracy of students' self-assessment and their beliefs about its utility. Assessment and Evaluation in Higher Education, 35(2), 135-156.

Lewis-Beck, M., Bryman, A., \& Liao, T. (2004). The SAGE Encyclopedia of Social Science Research Methods, Vol. III. California: SAGE Publications.

Light, G., \& Cox, R. (2003). Learning and Teaching in Higher Education: The Reflective Professional. London: Sage Publications.

Lindblom-Ylänne, S., Trigwell, K., Nevgi, A., \& Ashwin, P. (2006). How approaches to teaching are affected by discipline and teaching context. Studies in Higher Education, 31 (3): 285-298.

Lizzio, A., \& Wilson, K. (2013). First-year students' appraisal of assessment tasks: implications for efficacy. Engagement and performance. Assessment and Evaluation in Higher Education, 38(4), 389-406.

Lueddeke, G. (2003). Professionalising teaching practice in higher education: a study of disciplinary variation and 'teaching-scholarship. Studies in Higher Education, 28: 213228.

Marton, F. \& Säljö, R. (1997). Approaches to learning. In F. Marton, D. Hounsell \& N. Entwistle (Eds.), The experience of learning. Implications for teaching and studying in higher education (pp. 39-59). Edinburgh: Scottish Academic Press.

McDowell, L. \& Mowl, G. (1996). Innovative assessment - its impact on students. In G. Gibbs (Ed.), Improving student learning through assessment and evaluation, (pp. 131147). Oxford: The Oxford Centre for Staff Development. 
McGarr, O. \& Clifford, A. (2013). 'Just enough to make you take it seriously': exploring students' attitudes towards peer assessment. Higher Education, 65 (6), 677693.

Ministry of Science, Technology and Higher Education (2005). Decree Law no. 42/2005. Lisbon.

Mok, M., Lung, C., Cheng, D., Cheung, R., \& Ng, M. (2006). Self-assessment in higher education: experience in using a metacognitive approach in five case studies. Assessment and Evaluation in Higher Education, 31 (4), 415- 433.

Mälardalen University (2015a). Education plan for Initial Teacher Education, Preschool and year 1-3, 240 ECTS. Västerås.

Mälardalen University (2015b). Course plan for Development work and evaluation/Utvecklingsarbete och utvärdering, 7,5 ECTS. Västerås.

Mälardalen University (2015c). Regler och anvisningar för examinationsärenden på grundnivå och avancerad nivå vid Mälardalens högskola [Rules and regulations for exam issues on first cycle and second cycle (advanced level) at Mälardalen University]. Västerås.

Nieweg, M. (2004). Case study: innovative assessment and curriculum redesign. Assessment and Evaluation in Higher Education, 29 (2), 203-214.

Norrie, E. (2003). Mark my words: self and peer assessment as an aid to learning. European Journal of Engineering Education, 28 (1), 103-116.

Paris, S. \& Paris, A. (2001). Classroom applications of research on self-regulated learning. Educational Psychologist, 36 (2), 89-101.

Pereira, D., \& Flores, M. A. (2012). Percepções dos estudantes universitários sobre a avaliação das aprendizagens: um estudo exploratório. Avaliação (Campinas), 17 (2), $529-556$. 
Pereira, D., Flores, A. M., \& Niklasson, L. (2015). Assessment Revisited: a review of research in Assessment and Evaluation in Higher Education. Assessment and Evaluation in Higher Education. doi: 10.1080/02602938.2015.1055233.

Price, M., Rust, C., O’Donovan, B., Handley, K., \& Bryant, R. (2012). Assessment literacy: The foundation of improving student learning. Oxford: Oxford Centre for Staff and Learning Development.

Race, P. (1995). What has assessment done for us - and to us? In P. Knight (Ed.), Assessment for learning in higher education (pp. 61-74). London: Kogan Page.

Ramsden, P. (1992). Learning to teach in higher education. London: Routledge.

Rust, C. (2007). Towards a scholarship of assessment. Assessment and Evaluation in Higher Education, 32 (2), 29-37.

Sambell, K., \& McDowell, L. (1998). The construction of the hidden curriculum: messages and meanings in the assessment of student learning, Assessment and Evaluation in Higher Education, 23 (4), 391-402.

Sambell, K., McDowell, L., \& Brown, S. (1997). 'But is it fair?': an exploratory study of student perceptions of the consequential validity of assessment. Studies in Educational Evaluation, 23 (4), 349-371.

Scouller, K. (1998). The influence of assessment method on students' learning approaches: Multiple choice question examinations versus assignment essay. Higher Education, 35 (4), 453-472.

Segers, M. \& Dochy, F. (2001). New assessment forms in problem-based learning: the value added of the students' perspective. Studies in Higher Education, 26 (3), 327-343. 
Struyven, K., Dochy, F., \& Janssens, S. (2005). Students' perceptions about evaluation and assessment in higher education: a review. Assessment and Evaluation in Higher Education, 30 (4), 325-341.

Swedish Higher Education Authority (2015). http://www.uka.se/qualityassurance/qualityaspectsandconditionsonwhichdegreeawardin gpowersarebased.4.4149f55713bbd917563800010322.html\#h-Qualityaspects. Accessed 13 January 2015.

Taras, M. (2010). Student self-assessment: processes and consequences. Teaching in Higher Education, 15 (2), 199-209.

Teichler, U. (2014). Opportunities and problems of comparative higher education research: the daily life of research. Higher Education, 67 (4); 393-408.

Vickerman, P. (2009). Student Perspectives on Formative Peer Assessment: An Attempt to Deepen Learning? Assessment and Evaluation in Higher Education, 34 (2), 221-230.

Yorke, M. (2003). Formative assessment in higher education: moves towards theory and the enhancement of pedagogic practice. Higher Education 45 (4), 477-501.

Webber, K. (2012). The Use of Learner-Centered Assessment in US Colleges and Universities. Research in Higher Education, 53 (2), 201-228.

Weurlander, M., Söderberg, M., Scheja, M., Hult, H., \& Wernerson, A. (2012). Exploring formative assessment as a tool for learning: students' experiences of different methods of formative assessment. Assessment and Evaluation in Higher Education, 37(6), 747-760.

Yanowitz, K.L., \& Hahs-Vaughn, D. (2007). Changes in Student-centered Assessment by Postsecondary Science and Non-science Faculty. Teaching in Higher Education, 12: $171-84$. 